L.A.J.Al-HASSAN ${ }^{1}, A_{0} Y . A L .-A B O O D^{2}, A . A . A l-S E Y A B^{1}$

Fish physiology

\title{
SEASONAL VARIATIONS IN THE HAEMOGLOBIN CONCENTRATION AND HAEMATOCRIT VALUES OF SILURUS TRIOSTEGUS
}

\section{SEZONOWE ZMIANY KONCENTRACII HEMOGLOBINY I WARTOSCI HEMATOKRITU U SILURUS TRIOSTEGUS}

\author{
1 Dept of Fisheries Marine Resources, College of Agriculture, \\ University of Basrah, Basrah, Iraq \\ ${ }^{2}$ Dept of Biology, College of Science, University of Basrah, \\ Basrah, Iraq
}

\begin{abstract}
The peak values of haemoglobin concentration and haematocrit value in Silurus triostegus were found to be 9.42 $\mathrm{g} / 100 \mathrm{ml}$ and $25.23 \mathrm{respectively,} \mathrm{forthe} \mathrm{males.} \mathrm{For} \mathrm{the}$ females fish were $9.40 \mathrm{~g} / 100 \mathrm{ml}$ and 25.20 respectively. They were observed during the month October of the year. A marked decreased was observed in the value of the two parameters in April where the fish pass the maturation period. During the hot months of the year the haemoglobin concentration and haematocrit value show higher values than the cold months.
\end{abstract}

\section{INTRODUCTION}

It is well doccumented that the environment is considered as one of the most important factor that affect the physiology of the fish and that haematological parameters can give an indication of the patho-physiological state of the animal (Blaxhall \& Daisly, 1973). No observations concerning the normal seasonal effects on the haematology of the silurid fish, Silurus triostegus are available. The works of $\mathrm{Al}-\mathrm{Hassan}$ and Al-Abood (1988) and Al-Abood and Al-Hassan (1988) are considered the only works on the haematology of $S$. triostegus in the vicinity of Basrah. On the other hand, seasonal variations study was very well recorded for sevaral other fish species (Fourie \& Hattingh, 
1976; Fourie \& Vuren, 1976; Raizada et al., 1983; Arderson et al., 1985; and Hameed \& Jiad, 1986).

The aim of the present study is to make a brief account of the haematological astimation of $S$. triostegus during different months of the year and to see whether the haemoglobin concentration and haematocrit values may be used as an early indicator of breeding activity.

\section{MATERIALS AND METHODS}

The fish used in the present study were catched each month in the Shatt al-Arab River, north of Basrah city during the period March 1988 to February 1989.

For haemoglobin concentration estimation, blood was drawn into turbes containing EDTA as an anticaugulant either by a heart puncture (for large fish) or by the severing of the peduncle (for small fish). The haemoglobin concentration per $100 \mathrm{ml}$. of blood was determined by Sahli's haemometer as described by Radzinskaya (1966) and by Pandey et.al., (1976). For haematocrit value determination, the blood was drawn into microhaematocrit tubes containing EDTA as an anticauagulant. The blood samples were centrifuged for $5 \mathrm{~min}$ at $3000 \mathrm{rpm}$. Haematocrit values were determined according to the method of Blaxhall and Daisly (1973).

\section{RESULTS AND DISCUSSION}

The haemoglobin concentration and haematocrit value showed a marked variation in male and female fishes throughout the year. In male, the haemoglobin concentration and haematocrit value varied from $7.54-9.42 \mathrm{~g} / 100 \mathrm{ml}$. and $22.64-25.23$ respectively, while in females they varied from $7.50-9.40 \mathrm{~g} / 100 \mathrm{ml}$. and $22.60-25.20$ respectively (Table 1? . The peak values for those two haematological parameters were $9.42 \mathrm{~g} / 100 \mathrm{ml}$., 25.23 in the males and $9.40 \mathrm{~g} / 100 \mathrm{ml}$ and 25.20 in the females respectively were recorded during October. This peak in the proceeding months showed a registered fall till April. Later on in May they starts to take values higher than April. Haemoglobin concentration and haematocrit values were generally higher in males in all the months of the year than females (Table 1).

During the life cycle of the fish, blood undergoes regular changes of haemoconcention and haemodilution. These changes are mainly affected by the ecophysiological conditions of the fish (Khan, 19.77 and Joshi \& Randon, 1977). Different workers reported differnt time for the presence of the peak of the two haematological parameters in question. Chanchal et. al. (1979 (reported that the fish, Anabas testudeneus shows the peak values of haematocrit value in May and October. On the other hand, Joshi \& Tandon (1977) observed the peak values in May for Heteropenuestes fossilis and Mystus vittatus. In the present study, the peak of both haemoglobin concentration and haematocrit value for 
Monthly variations in the haemoglobin concentration and haematocrit value of Silurus triostegus. $M=$ males; $F=$ females;

$\mathrm{Hb}=$ haemoglobin concentration; $\mathrm{Ht}=$ haematocrit value

\begin{tabular}{|l|r|r|r|r|}
\hline & \multicolumn{2}{|c|}{ M } & \multicolumn{2}{|c|}{ F } \\
\hline & H b & Ht & H b & H t \\
\hline March & 7.94 & 22.70 & 7.92 & 22.67 \\
April & 7.54 & 22.64 & 7.50 & 22.62 \\
May & 8.53 & 24.30 & 8.50 & 24.28 \\
June & 8.54 & 24.30 & 8.51 & 24.27 \\
July & 8.56 & 24.28 & 8.54 & 24.26 \\
August & 8.59 & 24.20 & 8.58 & 24.19 \\
September & 9.00 & 24.26 & 8.94 & 24.23 \\
October & 9.42 & 25.23 & 9.40 & 25.20 \\
November & 8.20 & 25.10 & 8.15 & 25.09 \\
December & 8.10 & 24.98 & 8.09 & 24.96 \\
January & 8.00 & 24.94 & 7.97 & 24.92 \\
February & 7.98 & 24.80 & 7.94 & 24.76 \\
\hline
\end{tabular}

both sexes was in October and this coincide with the results of Chanchal et. al. (1979) and Raizada et. al. (1983). The peak in October may be suggested due to the favourable conditions of the environment and the higher metabolic activity of the fish, which lead to the more intake of food. The lowest values obtained in March and this could be due to the begining of the maturation period. It istrue that when the gonads are fully developed, fish consume very little amount of food because the major part of the body cavity is filled up by the developing gonads, resulting in low values of haemoglobin concentration and haematocrit. Lysaya (1951), Robertson et al. (1961) and Hulton (1967) have reported the same observations on Salmon undergowing spawing migration. The lower values during the cold months may be associated with the cold waether when the primary food production as wellas the metabolic rate of the fish slows down, resulting in low consumption of food. The higher haematological values during the summer months could be attributed to the increase in the level of adrenaline and nor adrenaline hormones due to the changes in the environment (Nakano a. Tomlinson 1967).

\section{ACKNOWLEDGEMENT}

Our sineer thanks are due to Mr. Saleh M.Al-Batran and Mr. Baha H. Jaber of the Najibia power plant. north of Basrah city for their help in obtaining fish speciemens. 


\section{REFERENCES}

Al-Abood, A.Y., and Al-Hassan, L.A.J., 1988: Haematocrit values in some freshwater fishes of Iraq. Basrah J. Agri. Sci., 1: 31-34.

Al-Haasan, L.A.J. and Al-Abood, A.Y., 1988: Preliminary studies on the haemoglobin concentration in some freshwater fishes of Iraq. Cybium, 12,1:17-21.

Anderson, A.A., J.S. Laursen and G. Lykkeboe, 1985: Seasonal variations in haematocrit, red cell haemoglobin and nueleoside triphosphate concentrations, in the European eel, Anguilla anguilla. Comp. Biochem. Physiol., 81A, 1: 87-92.

Blaxhall P.C., and K.W. Daisley, 1973: Routine haematological methods for use with fish blood. J. Fish. Biol., 5: 771-781.

Chanchal A.K., B.N. Pandey, S.B. Singh, and S. Prasad, 1979: Cyclic changes in haematologic values of Anabastestudeneus Ann. Zool., 15: 111-123.

Fourie F.R. and J. Hattingh, 1976: A seasonal study of the haematology of carp, Cyprinus carpio from a locality in the Transval, South Africa. Zoologica Africana, 11,1: 75-80.

Fourie F.R. and J.H.J. Van Vuren, 1976: A seasonal study on the haemoglobins of carp, Cyprinus carpio and yellowfish, Barbus holubi in South Africa. Comp. Biochem. Physiol, 55B: 523-525.

Hameed A.M. and J.H. Jiad, 1986: The relationship between age and blood constituents of Barbus xanthopterus (Heckel) in the different sẹasons from Sadat Al-Hindia, Iraq. J. Biol. Res. Centr., 17, $1: 77-86$.

Hutton K.E., 1967: Characteristics of the blood of adult pink salmon at three stages of maturity. Fishery Bull. Fish Widl. Ser., U.S.A., 66: 195-202.

Joshi B.D. and R.S. Tandon, 1977: Seasonal variations in haematologic values of freshwater fish, Heteropneustes fossilis \& Mystus vittatus. Comp. Physiol. Ecol., 2: 22-26.

Khan S.H., 1977: Study on haematology of freshwater catfish, Clarius batrachus. I. Seasonal variations in erythrocytes and leucocytes. Comp. Physiol. Ecol., 2: 88-92.

Lysaya E.M., 1951: Changes in the blood composition of salmon during the spawning migration. IZV. Tichookean. Nauchrissled. Inst. Ryb. Khoz. Okeanogr., 35: 47-60.

Nakano T. and N. Tomlinson, 1967: Catecol-amine and carbohydrate concentration in rainbow trout, Salmo gairdneri in relation to physical disturbance. J.Fish. Res. Bd. Can., 24: 1701-1715.

Pandey E.N., P.K. Pandey, E.J. Chouby and J.S. Datta Munshi, 1976: Studies on blood components of an airbreathing silurid fish, Heteropneustes fossillis (Bloch) in relation to body weight. Folia Haematologia, 103, 1: 101-116.

Radzinskaya L.I., 1966: Changes in the blood indices of juvenile and spawning Neva salmon, Salmo salar L., Vop. Ikthiol, 6: 568-572 (in Russian).

Raizada M.N., K.K. Jain and S. Raizada, 1983: Monthly variations in the Haematocrit values (PCV) in a teleost, Cirhinus mrigala (Ham.). Comp. Physiol. Ecol, 8, 3: 196-198.

Robertson C.H., M.A. Krupp, C.B. Favour, S. Hane and S.F. Thomas, 1961: Physiological changes occuring in the blood of the pacific salmon, Onchorhynchus tschawytscha accompanying sexual maturation and spawning. Endocrinology, 68: 733-748. 
L.A. Al-Hassan, A.Y. Al-Abood, A.A. Al-Seyab

\section{SEZON OWOŚĆ ZMIANY KONCENTRACJI HEMOGLOBINY I WARTOŚĆ HEMATOKRITU U SILURUS TRIOSTEGUS}

\section{STRESZCZENIE}

Autorzy przebadali poziom hemoglobiny i wartość hematokritu u Silurus triostegus w ciągu roku. Stwierdzono zmiany ilościowe w ciagu poszczególnych miesięcy i to zarówno u samców jak i samic.

Poziom hemoglobiny jak i wartość hematokritu były ogólnie wyższe u samców (p.tabela). Najwyższe wartości występowały w listopadzie, a najnišze w kwietniu. Najwyższe wartości dotyczyły miesięcy letnich.

Author's address:

Received: 1990.04 .06

L.A.J. Al-Hassan

Department of Fisheries Marine Resources

College of Agriculture, University of Basrah

Basrah, Iraq 